\title{
Soil carbon, nitrogen and texture dynamics at root zone and between plants in Riverine plantation of Acacia catechu, Dalbergia sissoo, Phyllanthus emblica and Eucalyptus camaldulensis
}

\author{
Ram Asheshwar Mandal a,*, Ishwar Chandra Dutta b, Pramod Kumar Jha a
}

a Central Department of Botany, Tribhuvan University, Kirtipur, Nepal

b Tribhuvan University Service Commission, Kirtipur, Nepal

\begin{abstract}
This research was objectively carried out to assess the dynamic of carbon, nitrogen and texture at root zone and location between plants. The plantation of Acacia catechu, Dalbergia sissoo, Phyllanthus emblica and Eucalyptus camaldulensis of Pragati community forest, Mahottari district, Nepal was selected for this study which was done in 2011. The stratified random sampling was applied to collect soil samples. Altogether 320 soil samples were collected from 0-10, 10-30, 30-60 and 60-90 cm depths. The result showed that soil carbon was about $8.16 \mathrm{tha}^{-1}$ at root zone which was only $7.56 \mathrm{t} \mathrm{ha}^{-1}$ at location between plants at $0-10 \mathrm{~cm}$ depth in Phyllanthus emblica stratum. The soil carbon was the least nearly $2.08 \mathrm{t} \mathrm{ha}^{-1}$ at root zone which was $1.59 \mathrm{t} \mathrm{ha}^{-1}$ at location between plants in Eucalyptus camaldulensis stratum. The carbon percentage was the highest about $1.35 \%$ at root zone of Phyllanthus emblica stratum. However, the $\mathrm{C} / \mathrm{N}$ ratio was the highest about 69:1 at location between plants of Dalbergia sissoo stratum. The texture of soil was loamy sand at root zone in Phyllanthus emblica, Acacia catechu and Dalbergia sissoo plantations while it was sandy at both root zone and between plants of Eucalyptus plantation. Plantations have significant effect on soil carbon and nitrogen at 95\% confidence level.
\end{abstract}

Keywords: Root zone, plants carbon, nitrogen, soil texture.

(C) 2018 Federation of Eurasian Soil Science Societies. All rights reserved

\section{Introduction}

The plant is the most capable living component to conserve and restore the soil, reduce the erosion and retain the fertility (Durán Zuazo and Rodríguez Pleguezuelo, 2008; Stokes et al., 2009). The canopy and crown of plants slow down the speed of the rainfall to reach the land surface (Holder and Gibbes, 2017). Plants like grass, ground covers, shrubs, and trees can help to stabilize river embankments through root system to hold the soil minerals (Preti and Giadrossich, 2009). The vegetations absorb rain water to reduce the surface runoff rate. In addition, the plants importantly stop to wash out the soil particles (Doran and Zeiss, 2000; Karlen et al., 2001). So, the plantations play a vital role to reduce hazards due to flood, land slide and bank cutting due to river (De Baets et al., 2007; Karoshi and Nadagoudar, 2012). Meanwhile plants play a key role to sequestrate the carbon and maintain soil fertility enhancing Nitrogen. Especially the natural hazardous is severe at exposed land area in comparison to vegetated land. Therefore, plantation especially at the bank of the river and surrounding has great importance to conserve the soil.

Globally, climate change is serious issue and one of the extreme effects is river flood (van den Honert and McAneney, 2011; Kundzewicz et al., 2013). The evidences are the severe flood in 2000 in Mozambique that

\footnotetext{
* Corresponding author.

Central Department of Botany, Tribhuvan University, Kirtipur, PO Box 44618, Nepal

Tel.: :+ 97719841450564
}

e-ISSN: 2147-4249

E-mail address: ram.mandal@gmail.com DOI: 10.18393/ejss.340719 
killed thousands of citizens (Aderogba et al., 2012). One of the most devastating floods occurred in southern Alberta, Canada in 2004 (Buttle et al., 2016) which damaged many health and wealth. The heavy torrential rains caused floods in Kyushu, Japan, killed 32 people (Takezawa et al., 2014). The Cyclone Ita flood killed 21 people in Solomon Islands (Davidson, 2014). The heavy rainfall in Visakhapatnam, India in 2014 destroyed many things and made thousands more homeless (Ramuje and Rao, 2014). The mass slide killed two dozen citizens in Sindhupalchok, Nepal in 2014 (Mol, 2014; MoHA, 2015). The best option is restoration of soil through plantation and river training to protect the land and lives (Aston, 1979) on the earth.

The plantation of Acacia catechu, Dalbergia sissoo, Eucalyptus camaldulensis and Phyllanthus emblica was carried out targeting to control the soil erosion and minimize the effects of flood at Pragati community forest, Mahottary district Nepal. On the other hand, the plantation has high positive effect on soil carbon (C), nitrogen (N) and texture formation (Hofstede et al., 2002; Kooch and Zoghi, 2015; Li et al., 2017) but the research regarding the contribution of plantation was not done yet. Moreover, it is more interesting fact that the soil carbon, nitrogen and texture are so sensitive to the vegetation that these were differed even at "root zone" and "location between the plants (about 1-1.25m away from root zone)" as well. Therefore, this study was objectively carried to assess the soil carbon, nitrogen and texture dynamics at root zone and location between plants of riverine plantation of Acacia catechu, Dalbergia sissoo, Phyllanthus emblica and Eucalyptus camaldulensis.

\section{Material and Methods}

Pragati community forest of Mahottary district, Nepal was selected for this study because the community forest was established at bank of the Ratu river where plantation of four species specifically Acacia catechu, Dalbergia sissoo, Phyllanthus emblica and Eucalyptus camaldulensis were done in 2011. The plantation is

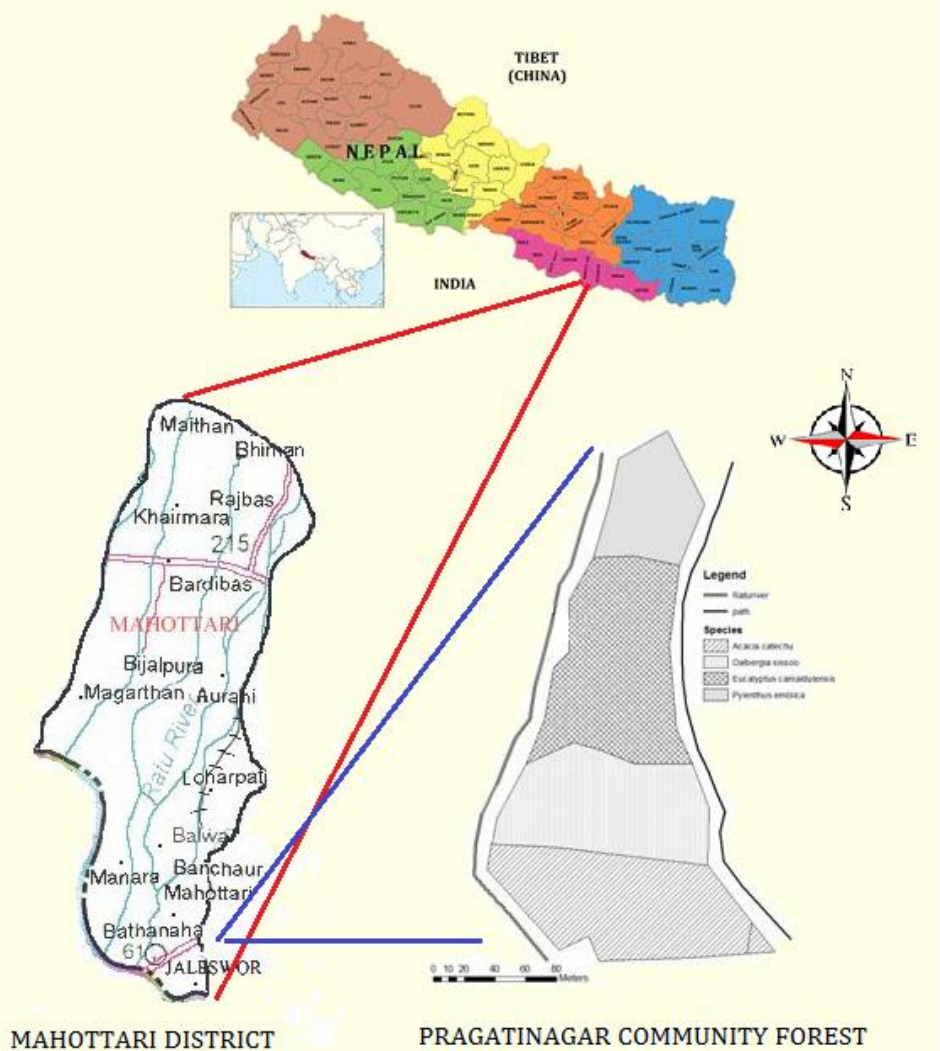

Figure 1. Experimental site about five years old. The purpose of the plantation was to control soil erosion and bank cutting caused by Ratu river. Geographically, Mahottary district is located at $26^{\circ} 36^{\prime}$ to $28^{\circ}$ $10^{\prime} \mathrm{N}$ and $85^{\circ} 41^{\prime}$ to $85^{\circ} 57^{\prime} \mathrm{E}$ (Figure 1). The temperature of this district ranges between 20$45{ }^{\circ} \mathrm{C}$ and average annual rainfall has been recorded between 1100-3500 $\mathrm{mm}$.

\section{Experimental design and sampling method}

The whole plantation area was considered as one block. The block was categorized into four strata according to species. Hence stratified random sampling was applied setting randomized block design (Kothari, 2004). The map of whole plantation area was prepared and stratified. Altogether 320 points for soil samples were marked on the map in such way that 160 points laid close to the root of the plant called "root zone" and same number of points were laid at the midpoint of two plants named as "location between plants". The spacing was maintained $2-2.5 \mathrm{~m}$ between plants. In fact, 20 samples were collected from each species strata specifically 10 samples from root zone and same number of samples from location between plants (Winner, 2009).

The soil samples were collected from four soil depths particularly from 0-10, 10-30, 30-60 and 60-90cm using soil corer (IPCC, 2006).

\section{Soil Analyses}

Collected soil samples were analyzed in the lab. Soil carbon, nitrogen, and C/N were analyzed. The soil texture (sand, silt and clay) was estimated using feel analysis (Thien, 1979). Field-moist samples from both sampling batches were gently and manually crumbled and sieved $(<8 \mathrm{~mm})$ in order to remove the root material. Each sample was thoroughly mixed and stored at field humidity in polyethylene bags until 
analyses. Soil analyses were conducted on air-dried samples from which crop residues, root fragments and rock larger than $2 \mathrm{~mm}$ had been removed and stored at room temperature. Some soil analyses were determined by the following methods: soil texture by the Bouyousoc hydrometer method (Anderson and Ingram, 1993), total Nitrojen by digestion and subsequent measurement conducted by the Kjeldahl method (Kjeldahl, 1883). All soil samples were sieved through a $150 \mu \mathrm{m}$ mesh to determine the total organic carbon content by the wet oxidation method (Walkley-Black) with $\mathrm{K}_{2} \mathrm{Cr}_{2} \mathrm{O}_{7}$ (Walkley and Black, 1958). C/N ratio in soils were calculated as total organic carbon / total nitrogen.

\section{Statistical Analysis}

The descriptive analysis was carried out to find the mean, standard deviation and standard error of the soil carbon of different stratum. At the same time, distributions of data were examined using KolmogorovSmirnov and Shapiro-Wilk tests to evaluate the normality of the data. Next, the t-test was applied to compare the carbon in total and at different depth at the location root zone and between the plants (Kothari, 2004).

\section{Results and Discussion}

\section{Soil carbon dynamics at root zone and between plants}

The soil carbon was differed at root zone and location between plants according to species. In case of Phyllanthus emblica, this was more about $8.16 \mathrm{t} \mathrm{ha}^{-1}$ at root zone which was $7.56 \mathrm{t} \mathrm{ha}^{-1}$ at location between plants at $0-10 \mathrm{~cm}$ depth. This was decreased according to increasing soil depths. In addition, soil carbon was the least nearly $2.08 \mathrm{t} \mathrm{ha}^{-1}$ at the root zone which was $1.59 \mathrm{t} \mathrm{ha}^{-1}$ at location between plants in Eucalyptus camaldulensis stratum. This indicates that the capacity of soil carbon formation was the highest of Phyllanthus emblica while it was the least of Eucalyptus camaldulensis. The reason behind this was leaf decomposition of leaf litter of Phyllanthus emblica was faster than the leaves of Eucalyptus camaldulensis. At the same time values of soil carbon were also high about 7.85 and $5.83 \mathrm{t} \mathrm{ha}^{-1}$ at root zone of Acacia catechu and Dalbergia sissoo. The study importantly showed that Phyllanthus emblica, Acacia catechu and Dalbergia sissoo are favorable species for soil formation in comparison to Eucalyptus camaldulensis. Moreover, there were significant differences in soil carbon between the location root zone and between plants at $95 \%$ confidence interval at different soil depth. This showed that the soil carbon formation in riverine areas was higher at the root zone than other place, since the microbial activities are high in soil near the root (Table 1).

Table 1. Status of soil carbon

\begin{tabular}{llllll}
\hline \multirow{2}{*}{ Species } & Details & \multicolumn{3}{c}{ Soil carbon t ha-1 according to soil depth } \\
\cline { 3 - 5 } & & $\mathbf{0 - 1 0} \mathbf{~ c m}$ & $\mathbf{1 0 - 3 0} \mathbf{~ c m}$ & $\mathbf{3 0 - 6 0} \mathbf{~ c m}$ & $\mathbf{6 0 - 9 0} \mathbf{~ c m}$ \\
\hline Phyllanthus & Root zone & 8.16 & 6.84 & 4.93 & 3.69 \\
\multirow{2}{*}{ Acacia catechu } & Between Plant & 7.56 & 6.43 & 3.28 & 3.02 \\
& Difference/p-value (t-test) & $0.50 / 0.01$ & $0.41 / 0.02$ & $1.65 / 0.00$ & $0.67 / 0.01$ \\
& Root zone & 7.85 & 6.35 & 3.04 & 3.02 \\
Dalbergia sissoo & Between Plant & 3.69 & 3.02 & 2.9 & 2.64 \\
& Difference/p-value (t-test) & $4.16 / 0.00$ & $3.33 / 0.00$ & $0.14 / 0.00$ & $0.38 / 0.00$ \\
& Root zone & 5.83 & 4.58 & 4.29 & 1.89 \\
Eucalyptus & Between Plant & 2.64 & 1.84 & 1.84 & 1.78 \\
camaldulensis & Difference/p-value (t-test) & $3.19 / 0.01$ & $2.74 / 0.00$ & $2.45 / 0.00$ & $0.11 / 0.40$ \\
& Root zone & 2.08 & 1.62 & 1.22 & 0.72 \\
& Between Plant & 1.59 & 1.12 & 0.74 & 0.25 \\
& Difference/p-value (t-test) & $0.49 / 0.00$ & $0.5 / 0.01$ & $0.48 / 0.00$ & $0.47 / 0.00$ \\
\hline
\end{tabular}

The mean carbon of soil was the highest nearly $23.62 \mathrm{t} \mathrm{ha}^{-1}$ at root zone of Phyllanthus emblica stratum while this was the lowest $3.7 \mathrm{t} \mathrm{ha}^{-1}$ at location between plants of Eucalyptus camaldulensis. There were significant differences in soil carbon at the root zone and location between plants in different plantation strata at 95\% confidence level. The maximum and minimum records of soil carbon were 25.86 and $22.21 \mathrm{t}$ ha $^{-1}$ respectively at the root zone of Phyllanthus emblica stratum (Table 2). The soil carbon in Eucalyptus camaldulensis stand was about $9.2 \mathrm{t} \mathrm{ha}^{-1}$ in Southern China (Du et al., 2015) which value was about to similar with this study.

\section{Carbon and nitrogen ratio at root zone and between plants}

The carbon percentage was the highest about $1.35 \%$ at the root zone of Phyllanthus emblica stratum but this was the least only $0.47 \%$ at location between plants in Eucalyptus camaldulensis stratum. However, the $\mathrm{C} / \mathrm{N}$ ratio was the highest about 69:1 at location between plants of Dalbergia sissoo stratum. 
Table 2. Summary statistics of carbon at root zone and location between plants

\begin{tabular}{llccccccc}
\hline Species & Location & $\begin{array}{c}\text { Mean C } \\
\text { t ha-1 }^{-1}\end{array}$ & $\begin{array}{c}\text { C difference } \\
\text { t ha-1 }^{-1}\end{array}$ & $\begin{array}{c}\text { p-value } \\
\text { (t-test) }\end{array}$ & Min. & $\begin{array}{c}\text { Max. } \\
\text { Standard } \\
\text { deviation }\end{array}$ & $\begin{array}{c}\text { Standard } \\
\text { error }\end{array}$ \\
\hline Phyllanthus & Root zone & 23.62 & 3.33 & 0.01 & 22.21 & 25.86 & 1.03 & 1.06 \\
emblica & Between Plants & 20.29 & & & 18.92 & 21.60 & 0.94 & 0.88 \\
Acacia & Root zone & 20.26 & \multirow{2}{*}{8.01} & 0.00 & 20.26 & 20.51 & 0.08 & 0.03 \\
catechu & Between Plants & 12.25 & & & 11.22 & 13.32 & 0.66 & 0.43 \\
Dalbergia & Root zone & 16.59 & \multirow{2}{*}{8.49} & 0.00 & 14.26 & 19.71 & 1.99 & 0.63 \\
sissoo & Between Plants & 8.10 & & & 5.90 & 10.77 & 1.25 & 0.39 \\
Eucalyptus & Root zone & 5.64 & \multirow{2}{*}{1.94} & 0.00 & 3.34 & 4.11 & 0.08 & 0.25 \\
camaldulensis & Between Plants & 3.70 & & & 4.64 & 7.69 & 0.25 & 0.80 \\
\hline
\end{tabular}

The soil fertility is improving high at root zone of Acacia catechu stratum since the $\mathrm{C} / \mathrm{N}$ ratio was found to be the lowest here while it was the lowest rate of soil improving at location between plants of Eucalyptus camaldulensis stratum because $\mathrm{C} / \mathrm{N}$ ratio was nearly 61.00:1 (Table 3). High $\mathrm{C} / \mathrm{N}$ ratio can slow down the decomposition rate of organic matter and nitrogen depends up on the $\mathrm{C} / \mathrm{N}$ ratio (Swangjang, 2015). The higher the soil $\mathrm{C} / \mathrm{N}$ ratio the lower the decomposition process of organic matter and nitrogen because it can limit the ability of soil microbial activity (Wu et al., 2001). The $\mathrm{C} / \mathrm{N}$ ratio ranges $0.2: 1$ to 27.4:1 in plantation area in Northeastern United States Watersheds (Ross et al., 2011) and the highest ratio of this research was about similar to the $\mathrm{C} / \mathrm{N}$ ratio of at the location between plants in Acacia catechu stratum. Soil materials are affected due to $\mathrm{C} / \mathrm{N}$ ratio (Swangjang, 2015). The soil having very less $\mathrm{N} \%$ is considered as the very low fertile soil (Dawud et al., 2017).

Table 3. $\mathrm{C} / \mathrm{N}$ ratio in soil

\begin{tabular}{|c|c|c|c|c|c|c|c|}
\hline Species & Zone & С \% & C difference & N\% & $\mathrm{N}$ difference & $\begin{array}{l}\mathrm{C} / \mathrm{N} \\
\text { ratio }\end{array}$ & $\begin{array}{l}\text { Soil Fertility } \\
\text { Improvement }\end{array}$ \\
\hline \multirow[t]{2}{*}{ Phyllanthus emblica } & Root zone & 1.35 & \multirow{2}{*}{0.03} & 0.04 & \multirow{2}{*}{0.01} & $33.75: 1$ & \multirow{2}{*}{ High } \\
\hline & Between Plants & 1.32 & & 0.03 & & $44.00: 1$ & \\
\hline \multirow[t]{2}{*}{ Acacia catechu } & Root zone & 1.06 & \multirow{2}{*}{0.17} & 0.04 & \multirow{2}{*}{0.01} & $26.50: 1$ & \multirow{2}{*}{ High } \\
\hline & Between Plants & 0.89 & & 0.03 & & $29.67: 1$ & \\
\hline \multirow[t]{2}{*}{ Dalbergia sissoo } & Root zone & 0.89 & \multirow{2}{*}{0.2} & 0.02 & \multirow{2}{*}{0.01} & $44.5: 1$ & \multirow{2}{*}{ Low } \\
\hline & Between Plants & 0.69 & & 0.01 & & $69: 1$ & \\
\hline Eucalyptus & Root zone & 0.61 & \multirow{2}{*}{0.14} & 0.01 & \multirow{2}{*}{0.00} & $61.00: 1$ & \multirow{2}{*}{ Low } \\
\hline camaldulensis & Between Plants & 0.47 & & 0.01 & & $47.00: 1$ & \\
\hline
\end{tabular}

\section{Soil texture dynamics at root zone and location between plants}

The soil texture consists of proportion of sand, clay and silt. These were differed at root zone and location between plants. The texture of soil was loamy sand at root zone in Phyllanthus emblica, Acacia catechu and Dalbergia sissoo plantations while it was sandy at both root zone and between plants in Eucalytus camaldulensis. The finding showed that the Eucalytus camaldulensis has very poor capacity to form the soil in riverine site (Table 4). The percentage of sand, silt and clay was significantly differed at root zone and between plants at $95 \%$ level of confidence. The soil texture at the bank of the river and ocean is dominated by sandy soil (Matsui et al., 2015).

Table 4. Soil Texture Dynamics at Root zone and Location between plants in different stratum

\begin{tabular}{|c|c|c|c|c|c|}
\hline Species & Sites & Sand \% & Clay \% & Silt \% & Texture \\
\hline \multirow{3}{*}{$\begin{array}{l}\text { Phyllanthus } \\
\text { emblica }\end{array}$} & Root zone & 82.50 & 5.50 & 12.00 & Loamy sand \\
\hline & Between Plants & 89.00 & 4.25 & 6.75 & Loamy sand \\
\hline & Difference/p-value & $6.50 / 0.00$ & $1.25 / 0.00$ & $5.25 / 0.00$ & \\
\hline \multirow[t]{3}{*}{ Acacia catechu } & Root zone & 89.00 & 4.25 & 6.75 & Loamy sand \\
\hline & Between Plants & 96.50 & 2.25 & 1.25 & Sandy \\
\hline & Difference/p-value & $7.50 / 0.00$ & $2.00 / 0.00$ & $5.50 / 0.00$ & \\
\hline \multirow[t]{3}{*}{ Dalbergia sissoo } & Root zone & 89.80 & 3.5 & 6.70 & Loamy sand \\
\hline & Between Plants & 95.25 & 3 & 1.75 & Sandy \\
\hline & Difference/p-value & $5.45 / 0.00$ & $0.50 / 0.00$ & 4. $95 / 0.00$ & \\
\hline Eucalyptus & Root zone & 93.50 & 4.00 & 2.50 & Sandy \\
\hline \multirow[t]{2}{*}{ camaldulensis } & Between Plants & 95.50 & 3.50 & 1.00 & Sandy \\
\hline & Difference/p-value & $2.00 / 0.00$ & $1.00 / 0.00$ & $1.50 / 0.03$ & \\
\hline
\end{tabular}




\section{Conclusion}

The carbon and nitrogen were significantly varied at root zone and location between plants according to soil depths and species. The carbon and nitrogen were higher at root zone in comparison to between plants. The soil texture was recorded sandy loam in Phyllanthus emblica, Acacia catechu and Dalbergia sissoo strata but it was sandy in Eucalyptus camaldulensi stratum. The $\mathrm{C} / \mathrm{N}$ ratio was higher at location between plants than root zone. Mean soil carbon was the highest at root zone of Phyllanthus emblica but this was the lowest at the location between plants of Eucalyptus camaldulensis stratum. The research can be applied to choose the appropriate species for plantation in river reclaimed area. Further studies are essential to examine soil carbon formation in different sites according to the plants species.

\section{Acknowledgements}

We acknowledge the users group of Pragatinagar community forest for their permission and help to collect the soil samples. We also acknowledge Mr. Ram Dular Yadayav and staff of Directorate office of soil lab in Hetauda, Makwanpur for their sincere help to analyze the soil samples.

\section{References}

Aderogba, K., Oredipe, M., Oderinde, S., Afelumo T. 2012. Challenges of poor drainage systems and floods in Lagos Metropolis, Nigeria. International Journal of Social Sciences and Education 2(3): 412-427.

Anderson, J.M., Ingram, J.S.I., 1993. Tropical soil biology and fertility: A handbook of methods. $2^{\text {nd }}$ edition. CAB International, Wallingford, UK. 221p.

Aston, A.R., 1979. Rainfall interception by eight small trees. Journal of Hydrology 42(3-4): 383-396.

Buttle, J.M., Allen, D.M., Caissie, D., Davison, B., Masaki, H., Peters, D.L., Pomeroy, J.W., Simonovic, S., St-Hilaire, A., Whitfield, P.H., 2016. Flood processes in Canada: Regional and special aspects. Canadian Water Resources Journal 41(1-2): 7-30.

Davidson, H., 2014. Solomon Islands flash floods kill at least 21 people. The Guardian. Available at [access date: 02.07.2017]: https://www.theguardian.com/world/2014/apr/07/solomon-islands-flash-floods-kill-at-least-19people

Dawud, S.M., Vesterdal, L., Raulund-Rasmussen, K., 2017. Mixed-species effects on soil C and N stocks, C/N ratio and pH using a transboundary approachin adjacent common garden douglas-fir and beech stands. Forests 8(4): 95.

De Baets, S., Poesen, J., Knapen, A., Barberá, G. G., and Navarro, J. A., 2007: Root characteristics of representative Mediterranean plant species and their erosion-reducing potential during concentrated runoff. Plant and Soil 294(1-2): 169-183.

Doran, J.W., Zeiss, M.R., 2000. Soil health and sustainability: managing the biotic component of soil quality. Applied Soil Ecology 15(1): 3-11.

Du, H., Zeng, F., Peng, W., Wang, K., Zhang, H., Liu, L., Song, T., 2015. Carbon storage in a Eucalyptus plantation chronosequence in Southern China. Forests 6(6): 1763-1778.

Durán Zuazo, V.H., Rodríguez Pleguezuelo, C.R., 2008. Soil-erosion and runoff prevention by plant covers. A review. Agronomy for Sustainable Development 28(1): 65-86.

Hofstede, R.G.M., Groenendijk, J.P., Coppus, R., Fehse, J.C., Sevink, J., 2002. Impact of pine plantations on soils and vegetation in the Ecuadorian high andes. Mountain Research and Development 22(2):159-167.

Holder, C.D., Gibbes, C., 2017. Influence of leaf and canopy characteristics on rainfall interception and urban hydrology. Hydrological Sciences Journal 62(2): 182-190.

IPCC, 2006. Good practice guidance for national greenhouse gas inventories. Chapter 4: Agriculture, Forestry, And Other Land Uses (AFOLU). Intergovernmental Panel On Climate Change, Geneva, Switzerland.

Karlen, D.L., Andrews, S.S., Doran, J.W., 2001. Soil quality: Current concepts and applications. Advances in Agronomy 74: $1-40$.

Karoshi, V.R., Nadagoudar, B.S., 2012. Forest plantations for climate change mitigation -reviewing estimates of net primary productivity in forest plantations. Indian Journal of Agricultural Economics 67(1): 157-162.

Kjeldahl, J. 1883. Neue Methode zur Bestimmung des Stickstoffs in organischen Körpern. Zeitschrift für analytische Chemie 22(1): 366-383.

Kooch,Y., Zoghi, Z., 2015. Comparison of soil fertility of Acer insigne, Quercus castaneifolia, and Pinus brutia stands in the Hyrcanian forests of Iran. Chinese Journal of Applied \& Environmental Biology ( 5 ) : 899-905.

Kothari, C.R., 2004. Research Methodology, Methods and Techniques. New Age International (P) Ltd., Publishers, New Delhi, India. 284p.

Kundzewicz, Z.W., Kanae, S., Seneviratne, S.I., Handmer, J., Nicholls, N., Peduzzi, P., Mechler, R., Bouwer, L.M., Arnell, N., Mach, K., Muir-Wood, R., Brakenridge, G.R., Kron, W., Benito, G., Honda, Y., Takahashi, K., Sherstyukov, B., 2013. Flood risk and climate change: global and regional perspectives. Hydrological Sciences Journal 59(1): 1-28. 
Li, Y., Chen, Y., Wang, X., Niu, Y., Lian, J. 2017. Improvements in soil carbon and nitrogen capacities after shrub planting to stabilize sand dunes in China's Horqin Sandy Land. Sustainability 9(4): 662.

Matsui, N., Meepol, W., Chukwamdee, J.C., 2015. Soil organic carbon in Mangrove ecosystems with different vegetation and sedimentological conditions. Journal of Marine Science and Engineering 3(4): 1404-1424.

MoHA, 2015. Nepal Disaster Report. 2015. Ministry of Home Affairs. Government of Nepal. 66p. Available at [access date: 02.07.2017]: http://www.drrportal.gov.np/uploads/document/329.pdf

MoI, 2014. Report on Jure Landslide, Mankha VDC, Sindhupalchowk District. Ministry of Home Affairs. Government of Nepal. 29p. Available at [access date: 02.07.2017]: http://www.sabo-int.org/case/2014_aug_nepal.pdf

Preti, F., Giadrossich, F., 2009. Root reinforcement and slope bioengineering stabilization by Spanish Broom (Spartium junceum L.). Hydrology and Earth System Sciences 13: 1713-1726.

Ramuje, K., Rao, B.N.M., 2014. Hudhud cyclone - A severe disaster in Visakhapatnam. International Journal of Research in Engineering and Technology 39(16): 156-163.

Ross, D.S., Bailey, S.W., Lawrence, G.B., Shanley, J.B., Fredriksen, G., Jamison, A.E., Brousseau, P.A. 2011. Near-surface soil carbon, Carbon/Nitrogen ratio, and tree species are tightly linked across Northeastern United States watersheds. Forest Science 57(6): 460-469.

Stokes, A., Atger, C., Bengough, A.G., Fourcaud, T., Sidle, R.C. 2009. Desirable plant root traits for protecting natural and engineered slopes against landslides. Plant and Soil 324(1-2): 1-30.

Swangjang, K., 2015. Soil carbon and nitrogen ratio in different land use. International Conference on Advances in Environment Research 87: 36-40.

Takezawa, M., Gotoh, H., Suzuki, K., Kakehi, Y., Yamamoto, T., 2014. Assessment of the flood disaster management plans for the medical services in Tokyo and Fukuoka, Japan. Risk Analysis 47(1): 1-12.

Thien, S.J., 1979. A flow diagram for teaching texture by feel analysis. Journal of Agronomic Education 8(1):54-55.

van den Honert, R.C., McAneney, J., 2011. The 2011 brisbane floods: Causes, impacts and implications. Water 3(4): 1149-1173.

Winner, L., 2009. Applied Statistical Methods. Department of Statistics University of Florida, USA. Available at [access date: 02.07.2017]: http://www.stat.ufl.edu/ winner/statnotescomp/appstat.pdf

Wu, H.B., Guo, Z.T., Peng, C.H., 2001. Changes in terrestrial carbon storage with global climate changes since the last interglacial. Quaternary Sciences 21: 366-376. 